\title{
DOI 10.26886/2414-634X.2(21)2018.12
}

UDC: $37.013: 371.132: 371.27$

\section{TEACHER TRAINING: YESTERDAY, TODAY, FOR THE FUTURE O. Feshchenko}

College "Bereginya", Ukraine, Cherkasy

The author shows preparation of the teacher for the organization and conducting of examinations in different types of school in pre-revolutionary, Soviet and modern periods. The attention was paid to the results of scientific research, the contribution of domestic scientists to the development of the examination process, as well as certain problems in preparing teachers for independent examinations at the present stage of development of general secondary education. The procedure of conducting external independent assessment and training of pedagogical workers in the system of postgraduate education is revealed.

Key words: school, teacher, exam, external independent evaluation

Фещенко О. В. Підготовка вчителя: вчора, сьогодні, на майбутнє / колегіум «Берегиня», Україна, Черкаси

Розглянуто підготовку вчителя до організації й проведення екзаменів у школах різного типу в дореволюційний, радянський та сучасний періоди. Звернено увагу на результати наукових досліджень, внесок вітчизняних учених у розвиток екзаменаційного процесу, а також на певні проблеми в підготовці вчителів до незалежних іспитів на сучасному етапі розвитку загальної середньої освіти. Розкрито порядок проведення зовнішнього незалежного оцінювання та підготовку педагогічних працівників в системі післядипломної освіти.

Ключові слова: школа, учитель, екзамен, зовнішнє незалежне оцінювання. 
Постановка проблеми. У законі “Про загальну середню освіту” визначено, яким повинен бути вчитель. Це насамперед особа 3 високими моральними якостями, яка має належний рівень професійної підготовки, здатна забезпечувати результативність та якість своєї роботи. До цього можна додати, що вчитель має мати розвинені творчі й дослідницькі здібності, високий рівень інтелігентності, ерудованості, бути готовим до безперервної освіти. Як відомо, педагогічна професія належить до найдавніших, бо виникла на ранніх етапах розвитку людства й виконувала навчальну й виховну функції - передачі підростаючому поколінню набутого досвіду. Особливої уваги серед інших заслуговувало питання професійної підготовки вчителів до організації й проведення екзаменів у школах України. Це спонукало нас до застосування профресіографічного підходу, який базувався на інтеграції професійної педагогіки з іншими дисциплінами. Важливим $є$ цей підхід для нашого дослідження, оскільки маємо завдання провести порівняльний аналіз організаційнометодичного змісту екзаменів у контексті досліджуваної теми та в умовах нових вимог до якості загальної середньої освіти, динаміки профресійної підготовки вчителя до здійснення контролю за рівнем навчання учнів, зокрема проведення екзаменів. На нашу думку, аналіз має включати як історико-педагогічний аспект, так і нинішній психологопедагогічний для цілісного сприймання екзаменаційного процесу в розвитку сучасної української школи.

Як свідчать досліджувані джерела, проблема якісної професійної підготовки вчителів була актуальною в усі виокремлені нами історичні періоди: дореволюційний, радянський та період незалежної України. Історіографрічний аналіз дав підстави ствердити, що в дореволюційний період єдиної системи вирішення проблеми профресійної підготовки вчителів щодо організації та проведення екзаменів у шкільній освіті не 
встановлено, а виявлено лише окремі елементи в ході висвітлення сучасними дослідниками питань діяльності початкових і середніх навчальних закладів в Україні кінця XIX - початку XX ст. (Л. Березівська, Л. Бондар, Н. Дічек, О. Драч, Г. Іванюк, В. Курило, О. Петренко, О. Сухомлинська та ін.); система оцінювання знань учнів у різних типах початкової й середньої школи другої половини XIX початку XX ст. ( В. Багринець, О. Біляковська, О. Гур'янова, І. Канєвська, С. Остапчук, А. Предик, С. Рукасова, О. Савченко, С. Телешов, С. Чупахіна, В. Яценко та ін.). Дослідження цього питання показало, що науковці, вивчаючи стан розвитку шкільництва в Україні, одночасно фрагментарно висвітлювали окремі періоди й підготовку вчителів до організації та проведення екзаменів.

Мета статті: розкрити підготовку педагогічних працівників до організації й проведення екзаменів у різних типах шкіл та в різні історичні періоди.

Нами вивчено та здійснено аналіз наукових досліджень щодо визначеної проблеми насамперед в дореволюційний період. До цієї групи віднесено творчі напрацювання Н. Вессель «Підготовка вчителів для нижчих училищ і вчительських семінарій в Росії» (1891) [1], А. Нейфельд «Педагогічні семінарії для вчителів середніх навчальних закладів» (1891) [2], В.Петрова «Чого навчають у початкових народних училищах?» (1896) [3]. Аналіз їхніх творчих доробків та О. Духновича («Народна педагогія. На користь училищ і сільських вчителів» (1857) [4], Т. Лубенця («Звіт про заняття на тимчасових педагогічних курсах для народних учителів і вчительок Новозибковського повіту Чернігівської губернії» (1885), «Педагогічні бесіди»(1903) [5-6], Д. Розанова («Про продуктивність навчання в початковій школі» (1906) [7], Я. Руднєва («Про організацію навчальної справи в учительських семінаріях» (1913) [8] показав, що питанням 
удосконалення навчально-виховного процесу, методики підготовки вчителя в учительських семінаріях, на тимчасових педагогічних курсах до роботи в народній, початковій школі, училищах приділялася велика увага, а також питанням оплати праці, забезпечення умов життя та педагогічної діяльності вчителя присвячені роботи М.Третякова («Старий народний учитель» (1909) [9] , А. Тютрюмова («Громадське і юридичне становище народного вчителя» (1892) [10] та ін. Цінну інформацію в процесі дослідження одержали при опрацюванні наукової роботи дослідників В. Каменської, М. Феліксова, М. Корфа [11; 12], які розкрили стан народної освіти в Херсонській губернії. Вважаємо, що серед вищеназваних авторів особливий внесок у розвиток початкових шкіл, професійної підготовки вчителів зробив М. Корф. Він залишив велику педагогічну спадщину не лише про організацію навчально-виховного процесу, методику викладання предметів у школах, а й про контроль за рівнем знань учнів, проведення вступних, перевідних та випускних екзаменів. Вивчивши науковий доробок цього педагога та роботи науковців про його діяльність (І. Шумілова «М. Корф про професійну підготовку вчителя» (2006) [13], Н. Андрійчук «Підготовка вчителів народної школи в учительських семінаріях України (1860-1917рр.) (2017 ) [14], нами зроблено такі висновки: по-перше, одним із перших в історії розвитку української педагогіки та шкільництва він порушив проблему професійної підготовки майбутнього вчителя; по-друге, методично грамотно впливав на розвиток земської школи, а головне - на професійну підготовку земських учителів; по-третє, на базі Бердянської повітової школи було розпочато підготовку вчителів для сільських шкіл. При огляді земських шкіл перевіряв не лише знання учнів, але й методи викладання, проводив сам відкриті уроки арифмметики, письма, грамоти, пристосувавши кожний із них до 
конкретних умов школи та національності ії учнів. М. Корфр був переконаний в тому, що “справа в школах могла йти більш правильно, якби вчителі народних шкіл одержували освіту в спеціальних педагогічних навчальних закладах" [там само]. По-четверте, він був одним із організаторів вчительських курсів та професійних з'їздів як ефективних форм удосконалення підготовки вчителів. Так, на з'їзді (1883) обговорювалися питання щодо подальшого розвитку навчальної справи в школах, програм викладання в початкових народних училищах, організації бібліотек для учителів, початку навчання в школах і віку вступників до народних шкіл, термінів проведення проміжних і підсумкових іспитів учнів народних шкіл та ін. Для нашого дослідження важливе питання, що обговорювалося на з"їзді, щодо часу й способу проведення проміжних та підсумкових випробувань у народних училищах, системи іспитів. Педагог виступив на ньому із детальним роз'ясненням про цілеспрямований спосіб іспитів як для учнів, так і для випускників.

Отже, М. Корф як педагог, методист, громадський діяч у галузі народної освіти зробив значний внесок у професійну підготовку вчителів до запровадження екзаменів у школах дореволюційного періоду. Значимими для підготовки вчителів були і його роботи, у яких вміщено поради членам повітової училищної ради щодо проведення іспитів у початковій школі у другій половині 60-х років XIX століття. У роботі «Русская начальная школа. Руководство для земских гласных и учителей сельских школ» подано правила проведення, згідно з якими на екзамени відводився лише один день. Екзаменатору пропонувалося: у той час, коли йшло усне опитування однієї групи учнів, щоб інші виконували письмові завдання - $з$ арифметики, 3 російської мови, а тексти для читання, письмові вправи з російської мови, задачі 3 арифметики обов'язково добиралися 3 інших 
підручників. Проводити їх, на думку М. Корфа, повинен член повітової училищної ради, а не вчитель.

Аналіз урядових і міністерських документів показав, що підсумковий контроль повинен бути, однак його порядок та умови не були розроблені; по-друге, різні типи шкіл створювалися, а держава професійну підготовку вчителів не забезпечувала, тобто з'являлася така суперечність. На підтвердження цього висновку можуть слугувати приклади із організації навчання в школах для дорослих, недільних школах, школах грамоти та вечірніх тощо. Для названих типів шкіл недостатньо було вчителів, а котрі й працювали в них, то, переважно, не мали достатнього досвіду роботи з такою категорією учнів, заняття були нецікаві, відсутня новизна для слухачів, а тому недавні випускники народних шкіл ненадовго затримувалися в цих школах. Суперечність виявлялася й у тому, що рівень і якість викладання впливали на рівень знань учнів. А тому виникла потреба у відкритті учительських семінарій в усій Російській імперії, зокрема в Україні, основним завданням їх було підготувати якомога більше професійних учительських кадрів. Цю проблему розкрила С. Андрійчук у монографрії «Підготовка вчителів народної школи в учительських семінаріях України (1860-1917рр.), яка написана в 2010 році. Цінним у дослідженні вченої вважаємо є те, що вона «визначила характерні риси та тенденції науково-педагогічних матеріалів для професійної підготовки вчителів народних шкіл, зокрема:

- зростаючу зацікавленість науковців і прогресивної педагогічної громадськості в розробці наукових основ професійної підготовки вчителів;

- врахування рідномовності як обов'язкової умови якісної профресійної підготовки вчителя народної школи та й освіти народу загалом; 
- прагнення педагогів-науковців визначити основні вимоги до особистості й професійної кваліфікації вчителя народної школи».

До визначених ученою позицій додамо ще й таку: потреба у здійсненні контролю за рівнем знань учнів та станом викладання, у тому числі в організації та проведенні екзаменів як форми контролю в умовах розширення мережі різних типів шкіл, збільшення учнівської різновікової категорії.

Радянський період, який розпочався після революції 1917 року, характеризувався продовженням пошуку нових екзаменаційних форм, зокрема на зміну предметним екзаменам почали запроваджувати тестування, основним інструментом вимірювання якостей учнів стали тести. Розробкою та впровадженням тестів як методу діагностики займалися вітчизняні вчені: Г. Ващенко, Я. Чепіга, М. Третьяков та ін. У цей історичний період набували розвитку психолого-педагогічні погляди вітчизняних та зарубіжних учених, використовуючи на практиці ідеї європейських, американських, російських науковців, вітчизняні вчені заснували різні наукові школи, які сприяли розвитку та популяризації національної школи. Проте, як зазначає Л. Смолінчук [15], для цього періоду проблема підготовки фрахівців, зокрема педологів, до роботи з тестами хвилювала багатьох теоретиків і практиків. Особливість тестів полягала в тому, що вони застосовувалися залежно від цілей: психологічних чи педагогічних. Психологічний тест розглядався як тест, що вимірював рівень загальної обдарованості й окремих видів розумової діяльності, а педагогічний - вимірював динаміку шкільної успішності. Як наголосила І.Пєтухова у дисертаційній роботі «Тести 20-30-х років XX ст. у структурі української освітньої практики», що масове застосування методу тестів у школах стало можливим через незадоволеність традиційними формами оцінювання. Масові тестові обстеження, що 
не підкріплювалися серйозною перевіркою якості інструментарію, а на їх підставі переведення деяких учнів у класи для розумово відсталих дітей призводили до критики й незадоволення як громадськості, так і науковців. Розуміючи це, О. Залужний наголошував на необхідності перевірки існуючих і виробленні нових, більш досконалих методик [16; 17].

Аналіз різних джерел, у яких розкрито питання підготовки майбутніх учителів шкіл, показав, що й у період незалежної України використовувалися традиційні підходи до контролю за рівнем знань учнів, зокрема підсумкового, які не сприяли фрормуванню вмінь щодо об'єктивного оцінювання; вказали на основні причини такої проблеми: по-перше, зменшено тижневе аудиторне навчальне навантаження студентів, скорочено години педагогічних практик, що й призвело до браку часу для набуття теоретичних знань та практичних навичок про оціночну діяльність; по-друге, серед предметів профресійної підготовки вчителів відсутня окрема дисципліна, яка сприяла б фрормуванню знань, умінь та навичок щодо оцінювання діяльності учнів; по-третє, чотирибальна система оцінювання знань студентів не формує готовності майбутніх учителів до правильного застосування 12-бальної системи оцінювання, яка використовується в загальноосвітніх навчальних закладах. Погоджуємося із висновками автора щодо суперечливості вимог до оцінки навчальної діяльності учнів: з одного боку - вимога до ії̈ об'єктивності, а з другого - як засобу педагогічного впливу на учня, але стимулюючого характеру. До суджень автора додамо власні, суть яких випливає із основ історіографії оцінювання рівня навчання учнів у школах України. Дослідження переконали в тому, що в школах використовувалися різні види оцінювання й у різні історичні періоди: то словесне оцінювання, то бальне. Розглядаючи цю проблему в контексті концепції «Нова українська школа», доречно, на 
нашу думку, навчати студентів набувати теоретичних знань та практичних умінь використовувати обидва види оцінювання.

У ході дослідження виникла потреба ознайомитися із навчальними програмами та підручниками, за якими здійснюється професійна підготовка майбутніх учителів із питань контролю за рівнем знань, у тому числі, щодо проведення екзаменів як фрорми підсумкового контролю. Проаналізувавши підручники та практикуми з педагогіки, з'ясували, що питання здійснення контролю за рівнем знань учнів у процесі підготовки майбутніх учителів не в усіх підручниках достатньо викладено, в основному названо окремі поняття щодо здійснення контролю в навчальному процесі. Детальніше у підручнику «Педагогіка» (автор С. Максимюк) [18] розкрито принципи контролю, визначено сутність цього поняття, види контролю та їх роль у навчальному процесі, зокрема підсумкового. Автор не лише назвав вид контролю, а й розкрив методи, фоорми, терміни проведення підсумкового контролю у формі екзаменів, наголосив на їх процедурних елементах, подав поняття «державна атестація», «тестова й машинна перевірка знань», визначив їх переваги, назвав способи перевірки знань тощо. Дослідження показало, що кількість годин на вивчення основ педагогіки зменшується, а це негативно впливає на якість професійної підготовки майбутніх учителів.

Питання професійної підготовки вчителів до організації й проведення екзаменів розглядається і в системі післядипломної освіти, зокрема в системі підвищення їхньої кваліфікації. Необхідно при цьому відмітити, що із змінами в державній освітній політиці, які стосуються форм організації й проведення випускних екзаменів, проведення державної підсумкової атестації у формі ЗНО, вступних екзаменів до вишів зазнали оновлення зміст навчального плану та програми курсової підготовки вчителів. Запроваджено навчальні модулі: 
«Психолого-педагогічні засади тестування в сучасній школі», «Моніторинг якості освіти: національний та регіональний аспекти», «Оцінювання знань учнів (зовнішнє й внутрішнє): проблеми та шляхи вирішення» та ін.

В умовах запровадження освітніх реформ на сучасному етапі розширюється можливості $3 \mathrm{HO}$, це, у свою чергу, спонукає до професійної підготовки педагогічних кадрів до його проведення. Таку функцію покликаний виконувати Український центр оцінювання якості освіти спільно з регіональними центрами, яких в Україні дев'ять. У навчанні й сертифікації педагогічних працівників, залучених до проведення зовнішнього оцінювання, беруть участь обласні інститути післядипломної освіти, відповідальні за $3 \mathrm{HO}$ в районних (міських) відділах освіти, а також відповідальні за пункти проведення ЗНО. Особливість такого навчання відзначається тим, що педагогічні кадри вчаться виконувати єдині вимоги до процедури проведення зовнішнього незалежного оцінювання, дотримуватися правил і норм, що врегульовують функціонування пункту тестування, передбачених Регламентом [19]. Із залучених педагогічних працівників створюється персонал, який відповідно виконує посадові обов'язки відповідальних за пункти, їхніх помічників, інструкторів, чергових, уповноважених. У ході навчання застосовуються різні теоретичні та практичні методи: тренінги, практичні заняття, ділові ігри тощо. Готовність персоналу до роботи в пункті проведення $3 \mathrm{HO}$ визначається за допомогою тестконтролю (дистанційна фрорма навчання та сертифікації залучених працівників), а також практикується проходження онлайн-сертифікації на сайтах регіональних центрів. Працівники цих центрів розробляють «...питання для сертифікації відповідальних за пункти ЗНО, інструкторів та старших інструкторів, де застосовуються всі можливі форми тестових завдань, що сприяє засвоєнню залученими 
працівниками теоретичних знань і практичних навичок, отриманих під час навчання. Сертифікація відповідальних за пункт $3 \mathrm{HO}$ та старших інструкторів проводилася у формі онлайн - тестування, для чого ОРЦОЯО було розроблене відповідне програмне забезпечення, яке відповідає вимогам системи педагогічної діагностики:

- структура системи передбачає оцінювання знань технології проведення 3НО відповідно до посади в пункті ЗНО;

- контроль знань може бути організований відповідно до технологічних карт персоналу пункту $3 \mathrm{HO}$, а також за програмою всього курсу в цілому;

- результати контролю фріксують у базі комп'ютера, автоматично формуючи Відомість сертифікації залучених працівників певного регіону та Сертифікат відповідального за пункт ЗНО або старшого інструктора;

- система допускає багаторазове звернення до контролю, при цьому в базі оцінок повинні бути зафіксовані три останні оцінки;

- передбачено неповторюваність сукупності питань під час наступного тестування;

- система опрацьовує тести (завдання) різних форматів (завдання багатовибіркового типу, завдання на утворення логічних пар, завдання на відновлення хронологічної й логічної послідовності, завдання з короткою відкритою відповіддю);

- система передбачає індивідуальну роботу кожного користувача через сайт Одеського РЦОЯО без необхідності встановлення додаткового програмного забезпечення;

- система має модуль, який керує розмежуванням доступу (це необхідно для захисту інформації від несанкціонованого доступу різного рівня); 
- система має різні вихідні форми для контролю за проведенням сертифікації: для представника регіонального центру оцінювання якості освіти, для відповідального за організацію 3НО в певному територіальному окрузі, для фахівця, який проходить сертифікацію»

Наступний вид роботи в підготовці педагогічних кадрів до адміністрування ЗНО є дистанційне навчання, при якому найбільш ефективно можна використовувати мережеві сайти. Регіональні центри в співпраці 3 працівниками структурних підрозділів ОІПО використовують різні методи дистанційного навчання, а саме:

- методи навчання за допомогою взаємодії учасника ЗНО або педагогічного працівника з освітніми ресурсами при мінімальній участі методиста (експерта). Для розвитку цих методів характерний мультимедіа-підхід, коли за допомогою різноманітних засобів створюються освітні ресурси: друковані, аудіо- , відеоматеріали, презентації, навчальні матеріали, що доставляються з комп'ютерних мереж;

- методи індивідуалізованого викладання й навчання (навчання "один до одного"). Ці методи реалізуються в дистанційній освіті в основному за допомогою таких технологій, як телефон, голосова пошта, електронна пошта тощо;

- методи, в основі яких лежить подання слухачам навчального матеріалу викладачем, методистом чи експертом. Ці методи, властиві традиційній освітній системі, одержують новий розвиток на базі сучасних інформаційних технологій;

- методи, для яких характерна активна взаємодія між усіма учасниками навчального процесу (навчання "багато до багатьох"). Значення цих методів й інтенсивність їх використання істотно зростає із розвитком навчальних телекомунікаційних технологій [там само]. 
Отже, використання вище названих методів підготовки як абітурієнтів, так і вчителів до участі в зовнішньому незалежному оцінюванні допомагає успішно виконати процедурні завдання, які реалізуються на пунктах тестування.

Питаннями подальшого розвитку $3 \mathrm{HO}$ в Україні постійно опікуються Міністерством освіти і науки України, відповідним Комітетом Верховної Ради України, Національною академією педагогічних наук України, Українським центром оцінювання якості освіти, Спілкою ректорів вищих навчальних закладів України, а також Альянсом Програми сприяння зовнішньому тестуванню в Україні (Альянс USETI). Так, у 2015 році проведено V Міжнародну науково-методичну конференцію «Освітні вимірювання - 2015 [20]. Реформування зовнішнього незалежного оцінювання: методологія, модель, основні складові», на якій розглянуто питання щодо організації та проведення Міжнародних та національних моніторингових досліджень якості освіти в Україні, стану та різних напрямів удосконалення $3 \mathrm{HO}$ (система підготовки тестів та банк тестових завдань; оцінювання, шкалювання, інтерпретація, вирівнювання результатів 3НО; перспективні напрями розвитку системи 3НО: ДПА в фрорматі ЗНО (початкова, основна, старша школа); вступні тести $3 \mathrm{HO}$ на магістерські програми; кваліфікаційні й сертифікаційні тести для вчителів; запровадження тесту загальної навчальної компетентності (ТЗНК); комп'ютерне й комп'ютеризоване адаптивне тестування; інтеграція в світовий та європейський простори забезпечення якості освіти; аналітичні дослідження результатів 3НО: якість тестів 3НО; оцінювання якості загальної середньої освіти за результатами ЗНО; якість системи вступу до вишів за результатами $3 \mathrm{HO}$ та ін. Аналіз питань, які обговорювалися на цьому форумі, показав, що представники як системи загальної середньої освіти, так і вищої були однодумцями, 
внесли пропозиції: тестові технології доречно використовувати при проведенні випускних та вступних випробувань на різних етапах здобуття освіти.

Отже, з огляду на нові завдання, визначені сучасною освітньою політикою, варто продовжити практикувати підготовку педагогічних кадрів до запровадження процедури $3 \mathrm{HO}$ й в інших освітніх закладах (ПТУ, технікуми, коледжі, університети тощо). Разом із тим, необхідна професійна підготовка педагогічних кадрів до розробки якісних тестів, які використовуватимуться під час випускних та вступних незалежних іспитів на різних освітніх рівнях. На нашу думку, такі знання й уміння треба сорормувати насамперед в студентів вишів - майбутніх учителів закладів освіти.

\section{תimepamypa:}

1. Вессель Н. Приготовление учителей для низших училищ и учительских семинарий в России. Русская школа. - 1891. - Т. 1. Кн. 7-12. C. $25-44$.

2. Нейфельд А. Педагогические семинарии для учителей средних учебных заведений. Вестник воспитания. - 1891. - № 2. - С. 39-67.

3. Петров В. Чему учат в начальных народных училищах? Вестник воспитания. -1896. - № 6. - С. 61-89.

4. Духнович A. Народная педагогия. В пользу училищ и учителей сельских. Часть I : Педагогия общая. -Львов, 1857. - 92 с.

5. Лубенец T. Отчет о занятиях на временных педагогических курсах для народных учителей и учительниц Новозыбковского уезда Черниговской губернии. К.: Изд. Новозыбковской уездной земской управы, 1885. - 62 с.

6. Лубенец Т. Педагогические беседы. СПб.: П.В. Луковников, 1913. $578 c$. 
7. Розанов Д. О продуктивности обучения в начальной школе. Русская школа. - 1906. - № 5-6. Май-июнь. С. 86-98.

8. Руднев Я. И. Об организации и постановке ученого дела в учительських семинариях. Журнал Министерства Народного Просвещения. 1913. Часть XLV. Июнь. - С. 129-168.

9. Третьяков Н. Старый народный учитель. Русская школа. 1909. № 5-8. - C. 78-88.

10. Тютрюмов А. Общественное и юридическое положение народного учителя. Русская школа. 1892. - № 11. - С. 123-137.

11. Каменская В. Народное образование в Херсонской губернии. Русская школа. 1892. - № 3. - С. 132-138.

12. Корфр Н. А. Русская начальная школа. Руководство для земских гласных и учителей сельских школ. СПб.: Изд. Д. Е. Кожанчикова, 1872. $-274 c$.

13. Шумілова І. М. О. Корфф про профресійну підготовку вчителя. Рідна школа. - 2006. - № 6. - С. 75-77.

14. Андрійчук Н. М. Підготовка вчителів народної школи в учительських семінаріях України (1860-1917рр.): монографрія. Житомир: Вид-во ЖДУ, 2011. - 299 с.

15. Смолінчук Л. Використання методу тестів у вітчизняній педагогічній практиці 20-30-х рр. XX cm. Молодь і ринок. - 2011. - № 12 (83).

16. Залужний О. Метод тестів у нашій школі. Шлях освіти. - 1926. № 1. - C. 63-85.

17. Пєтухова I. О. Тестування в освіті України крізь призму розвитку психолого-педагогічної науки (кінець XIX - перша третина XX століття): дис. ... канд. пед. наук. - Житомир, 2013. - 220 с.

18. Максимюк С. П. Педагогіка: Навчальний посібник. К.: Кондор, 2009. $-670 c$. 
19. Постанова Кабінету Міністрів від 08.07.2015 № 533 «Про порядок проведення зовнішнього незалежного оцінювання та моніторингу якості освіти». URL: http://www.kmu.gov.ua/control/uk/cardnpd?docid=/ 248379779

20. Матеріали V Міжнародної науково-методичної конфреренції «Освітні вимірювання-2015. Рефрормування зовнішнього незалежного оцінювання: методологія, модель, основні складові»: Тези учасників конфреренції (30 вересня - 2 жовтня 2015, м. Одеса). URL: http://elibrary./ kubg.edu.ua/10568/1/Y_Kovbasenko_tezi_2015.pdf.

\section{References:}

1. Wessel N. Preparation of Teachers for Lower Schools and Teaching Seminars in Russia. Russian school. - 1891. - T. 1. Kn. 7-12. Pp. 25-44.

2. Neufeld A. Pedagogical Seminars for Teachers of Secondary Educational Institutions. Herald of education. - 1891. - No. 2. - P. 39-67.

3. Petrov $V$. What are they taught in primary folk schools? Herald of education. -1896 - No. 6. - P. 61-89.

4. Dukhnovich A. National pedagogy. In favor of schools and rural teachers. Part I: General education. -Levov, 1857. - 92 p.

5. Lubenets T. Report on classes in temporary pedagogical courses for folk teachers and teachers of Novozybkovsky district of Chernihiv province. K.: Izd. Novozybkovsky district zemstvo governor, 1885. - 62 pp.

6. Lubenets T. Pedagogical conversations. SPb .: P. V. Lukovnikov, 1913. 578 pp.

7. Rozanov D. On the productivity of teaching in elementary school. Russian school. - 1906. - No. 5-6. May-June Pp. 86-98.

8. Rudnev Y. I. On the organization and production of a scholarly affair in teacher's seminaries. Journal of the Ministry of Public Education. 1913. Part of HLV. June - P. 129-168. 
9. Tretyakov N. An old folk teacher. Russian school. 1909. No. 5-8. - P. 7888.

10. Ttutyumov A. Public and legal position of the national teacher. Russian school. 1892. - No. 11. - P. 123-137.

11. Kamenskaya V. People's education in the Kherson province. Russian school. 1892. - No. 3. - P. 132-138.

12. Corf N. A. Russian Elementary School. Guide for Zemstvo vowels and teachers of rural schools. St. Petersburg: Izd. WHERE. Kozhanchikova, 1872. - $274 p p$.

13. Shumilova I. M. O. Korf about teacher training. Native school - 2006. No. 6. - P. 75-77.

14. Andriichuk N. M. Training of teachers of the folk school in the Teacher Seminars of Ukraine (1860-1917): monograph. Zhytomyr: AWW, 2011 - 299 p.

15. Smolinchuk $L$. The use of the test method in the national pedagogical practice of the 20-30's of the twentieth century. Youth and the market. 2011. - No. 12 (83).

16. Zaluzhny O. Test method in our school. Education path. - 1926. - No. 1. - P. 63-85.

17. Petukhova I. O. Testing in the education of Ukraine through the prism of the development of psychological and pedagogical science (the end of the $X I X$ - the first third of the $X X$ century): diss. ... Candidate ped sciences Zhytomyr, 2013. - 220 p.

18. Maksimyuk S. P. Pedagogy: A manual. K.: Condor, 2009 - 670s.

19. Resolution of the Cabinet of Ministers dated 07.08.2015 № 533 "On the procedure for conducting external independent evaluation and monitoring of the quality of education". URL: http://www.kmu.gov.ua/control/uk/cardnpd?docid=/ 248379779 
20. Materials of the $V$ International Scientific-Methodical Conference "Educational Measurements-2015. Reforming external independent evaluation: methodology, model, main components ": Abstracts of the conference participants (September 30 - October 2, 2015, Odessa). URL: http://elibrary./ kubg.edu.ua/10568/1/Y_Kovbasenko_tezi_2015.pdf 